IRA-International Journal of Applied Sciences ISSN 2455-4499; Vol.07, Issue 01 (2017)

Institute of Research Advances

Pg. no. 34-41

https://research-advances.org/index.php/IRAJAS

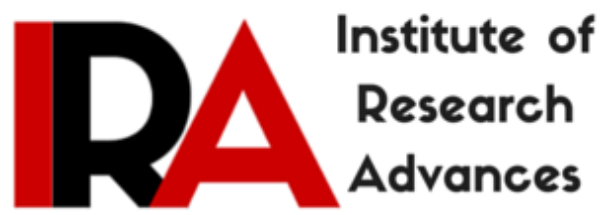

\title{
Abnormal Magnetic Moment and Zero Field Splitting of Some Nickel (II) Complexes
}

\section{Rajeev Ranjan ${ }^{1}$, Navneet Sinha ${ }^{2}$, Sahdeo Kumar ${ }^{3}$, Chandra Mauleshwar Chandra ${ }^{4}$, and Shivadhar Sharma ${ }^{5}$}

1,2,3,4,5 University Department of Chemistry, Magadh University, Bodh Gaya-824234,

Bihar, India.

Type of Review: Peer Reviewed.

DOI: http://dx.doi.org/10.21013/jas.v7.n1.p3

\section{How to cite this paper:}

Ranjan, R., Sinha, N., Kumar, S., Chandra, C., \& Sharma, S. (2017). Abnormal Magnetic Moment and Zero Field Splitting of Some Nickel (II) Complexes. IRA-International Journal of Applied Sciences (ISSN 2455-4499), 7(1), 34-41. doi:http://dx.doi.org/10.21013/jas.v7.n1.p3

(C) Institute of Research Advances

\section{(cc) EY-NC}

This work is licensed under a Creative Commons Attribution-Non Commercial 4.0 International License subject to proper citation to the publication source of the work.

Disclaimer: The scholarly papers as reviewed and published by the Institute of Research Advances (IRA) are the views and opinions of their respective authors and are not the views or opinions of the IRA. The IRA disclaims of any harm or loss caused due to the published content to any party. 


\section{ABSTRACT}

Some complexes of $\mathrm{Ni}(\mathrm{II})$ have been prepared with 2-thio-3-acetyl hydantoin (TAHN) and 2-formyl pyridine thiosemicarbazone (FPTS). On the basis of elemental analysis and molar conductivity, the complexes have been formulated as $\mathrm{NiL}_{2} \mathrm{X}_{2}$, where $\mathrm{L}=\mathrm{TAHN}$ or FPTS and $\mathrm{X}=\mathrm{Cl}^{-}, \mathrm{Br}^{-}, \mathrm{NCS}, \mathrm{ClO}_{4}^{-}$. The infrared spectra of complexes and free ligand reveal that the ligand TAHN is co-ordinated through sulphur and acetyl oxygen, while FPTS ligand co-ordinates through heterocyclic nitrogen and sulphur to $\mathrm{Ni}$ (II) metal ion. The magnetic moment of these complexes are found to be 3.20-3.25 B.M. The values are greater than $\mu_{s}$ value (2.828 B.M) corresponding to two unpaired electrons of a $d^{8}$-system. The appearance of four absorption bands in their electronic spectra reveal, the tetragonal distortion in the octahedral symmetry of complexes. The zero field splitting parameter $(D)$ and the other crystal field parameters like $D q_{(x y)}, D q_{(z)}$, Dt have been calculated. The results show that, the tetragonal distortion parameter (Dt) increases in the order of $\mathrm{NCS}<\mathrm{Cl}^{-}<\mathrm{Br}^{-}$while the zero field splitting parameter $(\mathrm{D})$ also increases in the same order for both the planer ligands.

$\underline{\text { Key words }}$ :- Heterocyclic nitrogen, Axial crystal field( $\left(D q_{z}\right)$, Tetragonal distortion parameters. INTRODUCTION

The ground term ${ }^{3} \mathrm{~F}$ of a d $\mathrm{d}^{8}$-system undergoes splitting due to octahedral (Oh) crystal field perturbation with ${ }^{3} \mathrm{~A}_{2} \mathrm{~g}$ as the ground state cubic field term ${ }^{1}$. As it is orbitally non-degenerate, no orbital contribution is expected to the magnetic moment of octahedral Ni(II) complexes and generally it comes to be nearly 2.828 B.M corresponding to two unpaired electrons. ${ }^{2,3}$ However several six co-ordinate complexes of $\mathrm{Ni}$ (II) with magnetic moment higher than expected (2.8 B.M) have been reported. ${ }^{4-9} \quad$ Such abnormal magnetic moment may arise due to mixing of several terms because of the lowering of symmetry by JahnTeller distortion. The departure of symmetry from perfect octahedron is generally not observed in Ni(II) complexes because, octahedral $\mathrm{d}^{8}$ is not electronically degenerate, but the presence of different ligands in co-ordination sphere may also cause deviation from octahedral symmetry. According to Ballhausen, the combined effects of a non cubic field and the spin orbit coupling in six co-ordinate $\mathrm{Ni}$ (II) complexes lead to zero field splitting of the ground state cubic field term ${ }^{10}$. In the cubic field the ground state ${ }^{3} \mathrm{~A}_{2} \mathrm{~g}$ is a three fold degenerate spin level. Its next excited state is ${ }^{3} \mathrm{~T}_{2} \mathrm{~g}$ which is triply degenerate which under the perturbation of a tetragonal field, splits into a two fold orbital degenerate level and a singly degenerate one. Now the spin orbit coupling energy may be regarded as a perturbation which couples the ground state together with the excited states. Subsequently, the spin multiplate of the ground state experiences the splitting of the excited states. In consequence to this the triplet spin levels of ${ }^{3} \mathrm{~A}_{2} \mathrm{~g}$ undergo a small splitting, which is called zero field splitting. The description of this class of distortion is subsequently in advance of the experimental facts ${ }^{11-12}$. We report here in the abnormal magnetic moment values of Six coordinate $\mathrm{Ni}$ (II) complexes with 2-thio-3-acetyl hydantoin and 2-formyl pyridine thiosemicarbazone and their zero field splitting.

\section{EXPERIMENTAL}

All the reagents used were of Anal. Grade procured from B.D.H. The ligand, 2-thio-3-acetyl hydantoin was prepared by the reaction of acetyl glycine and potassium thiocyanate whereby hydantoin separated as oil which instantly got solidified on stirring. It was recrystallised in ethanol and dried in desiccator. The other ligand i.e. 2 -formyl pyridine thio semicarbazone was prepared by the method reported earlier ${ }^{13}$. The yellowish white solid was recrystallised from methanol. These two ligands were used for complexation with $\mathrm{Ni}$ (II) salts by refluxing the metal salt with ligands taken in $1: 2$ molar ratio in ethanol. The elemental analysis was carried out using Perkin-Elmer 2400 C.H.N elemental analyzer. The IR spectra of the ligand and complexes were recorded on Perkin-Elmer FTIR spectrometer spectrum-two using $\mathrm{KBr}$ disc technique. The electronic spectra of the complexes were recorded on Perkin-Elmer UV/Vis spectrometer Lambda 25. The magnetic moment of complexes was determined on Gouy balance at room temperature using mercury tetrathiocyanatocobaltate(II) as calibrant. The molar conductivity of 
complexes was determined in DMF solution of $10^{-3} \mathrm{M}$ concentration on Elico Direct Reading Conductivity-meter.

\section{RESULT AND DISCUSSION}

The elemental analysis data and their molar conductivities values in DMF solution of $10^{-3} \mathrm{M}$ concentration of ligand as well as their $\mathrm{Ni}$ (II) complexes have been given in table-1, on the basis of which the complexes were formulated as $\mathrm{NiL}_{2} \mathrm{X}_{2}$ where $\mathrm{L}$ is 2-thio-3-acetyl hydantoin or 2-formyl pyridine thiosemicarbazone and $\mathrm{X}$ is $\mathrm{Cl}^{-}, \mathrm{Br}^{-}, \mathrm{NCS}^{-}, \mathrm{ClO}_{4}^{-}$.

Table - 1 Found/(Calculated)

\begin{tabular}{|c|c|c|c|c|c|c|c|c|c|}
\hline & $\begin{array}{l}\text { Ligand/ } \\
\text { complex }\end{array}$ & M & $\mathrm{C}$ & $\mathrm{H}$ & $\mathrm{N}$ & S & $\mathrm{Cl} / \mathrm{Br}$ & $\begin{array}{l}\lambda \mathrm{ohm}^{-1} \\
\mathrm{~cm}^{2} \mathrm{~mol}^{-1}\end{array}$ & $\begin{array}{l}\text { Experimental } \\
\text { calculated } \\
\mu(\mathrm{B} . \mathrm{M})\end{array}$ \\
\hline & TAHN & - & $\begin{array}{l}38.12 \\
(37.97)\end{array}$ & $\begin{array}{l}3.78 \\
(3.81)\end{array}$ & $\begin{array}{l}17.68 \\
(17.72)\end{array}$ & $\begin{array}{l}20.20 \\
(20.25)\end{array}$ & - & - & - \\
\hline & FPTS & - & $\begin{array}{l}47.00 \\
(46.67)\end{array}$ & $\begin{array}{l}4.00 \\
(4.45)\end{array}$ & $\begin{array}{l}30.0 \\
(31.1)\end{array}$ & $\begin{array}{l}17.64 \\
(17.78)\end{array}$ & - & - & - \\
\hline 1. & $\mathrm{Ni}(\mathrm{TAHN})_{2} \mathrm{Br}_{2}$ & $\begin{array}{l}10.25 \\
(10.97)\end{array}$ & $\begin{array}{l}23.00 \\
(22.44)\end{array}$ & $\begin{array}{l}2.00 \\
(2.24)\end{array}$ & $\begin{array}{l}10.00 \\
(10.47)\end{array}$ & $\begin{array}{l}12.00 \\
(11.96)\end{array}$ & $\begin{array}{l}30.00 \\
(29.92)\end{array}$ & 15 & $\begin{array}{l}3.12 / \\
(3.16)\end{array}$ \\
\hline 2. & $\mathrm{Ni}(\mathrm{TAHN})_{2} \mathrm{Cl}_{2}$ & $\begin{array}{l}13.00 \\
(13.17)\end{array}$ & $\begin{array}{l}27.50 \\
(26.92)\end{array}$ & $\begin{array}{l}3.00 \\
(2.69)\end{array}$ & $\begin{array}{l}13.00 \\
(12.56)\end{array}$ & $\begin{array}{l}14.03 \\
(14.36)\end{array}$ & $\begin{array}{l}16.00 \\
(15.93)\end{array}$ & 14 & $\begin{array}{l}3.23 / \\
(3.15)\end{array}$ \\
\hline 3. & $\mathrm{Ni}(\mathrm{TAHN})_{2}(\mathrm{NCS})_{2}$ & $\begin{array}{l}12.00 \\
(11.96)\end{array}$ & $\begin{array}{l}30.26 \\
(29.35)\end{array}$ & $\begin{array}{l}2.50 \\
(2.69)\end{array}$ & $\begin{array}{l}17.00 \\
(17.12)\end{array}$ & $\begin{array}{l}25.98 \\
(26.08)\end{array}$ & - & 18 & $\begin{array}{l}2.99 / \\
(3.4)\end{array}$ \\
\hline 4. & $\mathrm{Ni}(\mathrm{TAHN})_{2}\left(\mathrm{ClO}_{4}\right)_{2}$ & $\begin{array}{l}11.25 \\
(11.51)\end{array}$ & $\begin{array}{l}24.21 \\
(23.54)\end{array}$ & $\begin{array}{l}2.00 \\
(2.35)\end{array}$ & $\begin{array}{l}10.20 \\
(10.98)\end{array}$ & $\begin{array}{l}12.62 \\
(12.55)\end{array}$ & $\begin{array}{l}14.00 \\
(13.93)\end{array}$ & 142 & Diamagnetic \\
\hline 5. & $\mathrm{Ni}(\mathrm{FPTS})_{2} \mathrm{Br}_{2}$ & $\begin{array}{l}10.00 \\
(10.14)\end{array}$ & $\begin{array}{l}30.20 \\
(29.00)\end{array}$ & $\begin{array}{l}2.90 \\
(2.76)\end{array}$ & $\begin{array}{l}19.13 \\
(19.35)\end{array}$ & $\begin{array}{l}11.12 \\
(11.00)\end{array}$ & $\begin{array}{l}27.24 \\
(27.65)\end{array}$ & 15 & $\begin{array}{l}3.20 \\
(3.199)\end{array}$ \\
\hline 6. & $\mathrm{Ni}(\mathrm{FPTS})_{2} \mathrm{Cl}_{2}$ & $\begin{array}{l}12.00 \\
(11.98)\end{array}$ & $\begin{array}{l}35.12 \\
(34.30)\end{array}$ & $\begin{array}{l}3.20 \\
(3.27)\end{array}$ & $\begin{array}{l}22.32 \\
(22.87)\end{array}$ & $\begin{array}{l}13.51 \\
(13.07)\end{array}$ & $\begin{array}{l}14.00 \\
(14.49)\end{array}$ & 16 & $\begin{array}{l}3.16 \\
(3.156)\end{array}$ \\
\hline 7. & $\mathrm{Ni}(\mathrm{FPTS})_{2}(\mathrm{NCS})_{2}$ & $\begin{array}{l}11.00 \\
(10.97)\end{array}$ & $\begin{array}{l}36.35 \\
(35.90)\end{array}$ & $\begin{array}{l}3.00 \\
(2.99)\end{array}$ & $\begin{array}{l}25.89 \\
(26.18)\end{array}$ & $\begin{array}{l}23.48 \\
(23.94)\end{array}$ & - & 17 & $\begin{array}{l}3.15 \\
(3.16)\end{array}$ \\
\hline 8. & $\mathrm{Ni}(\mathrm{FPTS})_{2}\left(\mathrm{ClO}_{4}\right)_{2}$ & $\begin{array}{l}10.80 \\
(10.60)\end{array}$ & $\begin{array}{l}31.15 \\
(30.30)\end{array}$ & $\begin{array}{l}2.42 \\
(2.90)\end{array}$ & $\begin{array}{l}20.00 \\
(20.20)\end{array}$ & $\begin{array}{l}11.00 \\
(11.56)\end{array}$ & $\begin{array}{l}12.24 \\
(12.82)\end{array}$ & 145 & Diamagnetic \\
\hline
\end{tabular}

The molar conductivity values of complexes fall in between 14-18 $\mathrm{ohm}^{-1} \mathrm{~cm}^{2} \mathrm{~mol}^{-1}$ except two complexes i.e. complex no. (4) and (8) which exhibit comductivity value 142 and $145 \mathrm{ohm}^{-1} \mathrm{~cm}^{2} \mathrm{~mol}^{-1}$ respectively. It is indicative of the fact that these two complexs are $1: 2$ electrolyte while the rest complexes are non electrolyte in nature. ${ }^{14-15}$ Out of cumbersome spectra of ligands and complexes, the important bands of interest are interpreted here. The free ligand, 2-thio-3-acetyl hydantoin absorbs strongly at $3270 \mathrm{~cm}^{-1}$ due to $V_{\mathrm{N}-\mathrm{H}}$ stretching vibration. In complexes it does not show considerable change in its absorption frequency, which confirms the non co-ordination through ' $\mathrm{N}$ ' of the $\mathrm{N}-\mathrm{H}$ group to the metal ion. ${ }^{16-17}$ The absorption due to $V_{\mathrm{C}-\mathrm{N}-\mathrm{C}}$ moiety of the free ligand occurs at $1180 \mathrm{~cm}^{-1}$ which remains almost intact in the IR spectra of complexes indicating the non-involvement of other endocyclic ' $\mathrm{N}$ ' in co-ordination. In the region of $1600-1750 \mathrm{~cm}^{-1}$ the free ligand exhibit two absorption band i.e. one very strong at $1740 \mathrm{~cm}^{-1}$ and other strong at $1690 \mathrm{~cm}^{-1}$. The $>\mathbf{C}=\mathbf{O}$ group of acetyl group must absorb at 
higher frequency in respect of the other $>\mathbf{C}=\mathbf{O}$ group of the ligand due to $+\mathrm{I}$ effect of $-\mathrm{CH}_{3}$ group to $\mathbf{C}=\mathbf{O}$ of acetyl group. ${ }^{18-20}$ The other band at $1690 \mathrm{~cm}^{-1}$ may be due to vibrational frequency of $>\mathbf{C}=\mathbf{O}$ group attached to hydantoin ring. The band at 1690 remains unchanged in complexes while the band at $1740 \mathrm{~cm}^{-1}$ gets red shifted in the IR-spectra of complexes indicating co-ordination through acetyl oxygen to $\mathrm{Ni}(\mathrm{II})$. The other major change is observed in the absorption frequency of $\boldsymbol{V}_{\mathbf{C}=\mathbf{S}}$ which shifts from $1450 \mathrm{~cm}^{-1}$ in free ligand to nearly $1400 \mathrm{~cm}^{-1}$ in IR spectra of complexes, which is indicative of coordination through thionyl sulphur. ${ }^{21-23}$ Thus the first ligand i.e. 2-thio-3-acetyl hydantoin behaves as neutral bidentante, co-ordinating through acetyl carbonyl oxygen and thione sulphur forming six membered chelate ring. The other ligand 2-formyl pyridine thiosemicarbazone absorbs strongly at 3440 $\mathrm{cm}^{-1}, 3270 \mathrm{~cm}^{-1}$ and $3163 \mathrm{~cm}^{-1}$ due to $v_{\text {asym NH}}, v_{\text {sym NH}}$ and $v_{\left(\mathrm{NH}_{+} \mathrm{NH}_{2}\right)}$ respectively. ${ }^{24-27}$ In the spectra of complexes there is no considerable change in these absorption frequencies of free ligand. It shows that neither $-\mathrm{NH}$ nor $-\mathrm{NH}_{2}$ takes part in the co-ordination to the metal ion. The absorption band at $825 \mathrm{~cm}^{-1}$ due to $V_{>C=S}$ stretching vibration of the free ligand is found to have undergone red shift and appears at $740-770 \mathrm{~cm}^{-1}$ in the spectra of complexes. At the same time the combination band appearing at 1470 and $1300 \mathrm{~cm}^{-1}$ in free ligand due to $V_{>\mathrm{C}=\mathrm{S}}+v_{\mathrm{CN}}+v_{\mathrm{NH}_{2}}$ are found to have moved to slightly higher frequencies in all the four complexes. These facts predict the involvement of sulphur of the ligand in coordination to the $\mathrm{Ni}(\mathrm{II})$ ion. The pyridine ring vibrations occurring at 990,600 and $400 \mathrm{~cm}^{-1}$ in the free ligand undergo significant positive shift which indicate conclusively the co-ordination of ligand takes place via pyridine ring nitrogen. ${ }^{28-29}$ The aforesaid facts, thus reveal that the ligand, 2-formyl pyridine thiosemicarbazone acts as a neutral bidentate ligand co-ordinating through sulphur and heterocyclic nitrogen. The co-ordination through oxygen and sulphur in the complexes of first ligand and through nitrogen and sulphur in that of the second ligand is further confirmed by the appearance of some new bands in the spectra of complexes. The bands appearing at $500-525 \mathrm{~cm}^{-1}$ are assigned to $\square_{\mathrm{Ni}-\mathrm{O}}$ and bands at $450-455 \mathrm{~cm}^{-1}$ are assigned to $\square_{\mathrm{Ni}-\mathrm{N}}$ absorption frequency while the bands appearing at $350-370 \mathrm{~cm}^{-1}$ are assigned to $\square_{\mathrm{Ni-S}}$ absorption frequency. ${ }^{30-33}$ In the complexes number (1) (2) (5) and (6), two new bands of weak intensity appear at $275 \mathrm{~cm}^{-1}$ and $300 \mathrm{~cm}^{-1}$ which confirm the co-ordination through $\mathrm{Br}$ and $\mathrm{Cl}^{-}$respectively in these complexes. In complexes no. (3) and (7) the new bands appearing at 2083 $\mathrm{cm}^{-1}$ and $800 \mathrm{~cm}^{-1}$ shows the presence of NCS within their co-ordination sphere. ${ }^{34}$ The complexes no. (4) and (8) display a strong band at $1100 \mathrm{~cm}^{-1}$ which is indicative of the ionic nature of the $\mathrm{ClO}_{4}^{-}$ion in the complex. Vibrational band at $900 \mathrm{~cm}^{-1}$, indicative of co-ordinated $\mathrm{ClO}_{4}^{-}$is not observed in the IR spectra of the complexes which supports our assertion that the perchlorate ion is present as free ion. ${ }^{35-36}$

\section{MAGNETIC MOMENT AND ELECTRONIC SPECTRA}

The magnetic moment values of complexes are found 2.99 to 3.23 B.M. at room temperature while the complexes no. (4) and (8) are found diamagnetic. The $\square$ values are higher or abnormal in respect to $\square$ s value corresponding to two unpaired electrons in octahedral $\mathrm{Ni}$ (II) complexes. The higher values of $\square_{\text {effective }}$ of each complexes predict them to be a tetrahedral geometry where there is appreciable orbital contribution from ${ }^{3} \mathrm{~T}_{1 \mathrm{~g}}$ ground state of ${ }^{3} \mathrm{~F}$ term of $\mathrm{d}^{8}$-system. But on the basis of elemental analysis, IRspectra and molar conductivity values, the complexes are found six co-ordinate for which the ground state ${ }^{3} \mathrm{~F}$ of $\mathrm{d}^{8}$-system is ${ }^{3} \mathrm{~A}_{2 \mathrm{~g}}$, which is orbitally non degenerate. Hence it neither contributes to the magnetic moment to octahedral $\mathrm{Ni}$ (II) complexes nor does it splits by field of lower symmetry. However it has ${ }^{3} \mathrm{~T}_{2 \mathrm{~g}}$ as its next excited state which is orbitally triply degenerate. Under such circumstances, Ballhausen ${ }^{10}$ suggested that the strong spin orbit coupling promotes the spin orbit components of the triply degenerate excited state interact with the spin component of the ground state. This results in the splitting of the triplet spin state of ${ }^{3} \mathrm{~A}_{2 \mathrm{~g}}$ and triplet orbital degeneracy of ${ }^{3} \mathrm{~T}_{2 \mathrm{~g}}$. The extent of splitting of the triplet spin state of ${ }^{3} \mathrm{~A}_{2 \mathrm{~g}}$ is called zero field splitting represented by ' $\mathrm{D}$ ' while the extent of splitting of ${ }^{3} \mathrm{~T}_{2 \mathrm{~g}}$ is the measure of tetragonal distortion represented by $K_{1}$. The two splitting factors are correlated by $D=9 \cdot K_{1} \cdot \square^{2} / \square^{2}$, where $\square=10 \mathrm{Dq}$ and $\square$ is spin orbit coupling constant, which is $315 \mathrm{~cm}^{-1}$ with negative sign ${ }^{37}$. Due to spin orbit coupling the $\square_{\text {effective }}$ is given by, $\square_{0}(1-\square \square \square / \square$ ) where $\square=4$ for high spin Ni(II) complexes, $\square=10 \mathrm{Dq}$ and $\square_{0}=\square_{\text {spin }}$ only. This explains as to why the $\square_{\text {effective }}$ values of Ni(II) complexes no. (1), (2), (3), (5), 
(6) and (7) are higher than spin only value. ${ }^{38}$ The complexes no. (4) and (8) display three absorption bands in their electronic spectra which is indicative of square planer symmetry around $\mathrm{Ni}$ (II) in these two complexes. In their true $\mathrm{C}_{2 \mathrm{~V}}$ symmetry, these bands may be assigned to the following spin allowed transitions $\square_{1}\left({ }^{1} \mathrm{~B}_{1 \mathrm{~g}} \leftarrow{ }^{1} \mathrm{~A}_{1 \mathrm{~g}}\right), \square_{2}\left({ }^{1} \mathrm{~A}_{2 \mathrm{~g}} \leftarrow{ }^{1} \mathrm{~A}_{1 \mathrm{~g}}\right)$ and $\square \square_{3}\left({ }^{1} \mathrm{~B}_{2 \mathrm{~g}} \leftarrow{ }^{1} \mathrm{~A}_{1 \mathrm{~g}}\right){ }^{39-40}$. The square planer geometry of these complexes is also supported by their diamagnetic character. The rest complexes display four bands in their electronic spectra which are indicative of axially distorted octahedral symmetry around $\mathrm{Ni}$ (II) in these complexes. Under $\mathrm{D}_{4 \mathrm{~h}}$ symmetry these bands may be assigned to the following transitions. ${ }^{37,41}$

$$
\begin{array}{ll}
\square_{1}={ }^{3} \mathrm{E}_{\mathrm{g}}^{\mathrm{a}} \leftarrow{ }^{3} \mathrm{~B}_{1 \mathrm{~g}} & 10 \mathrm{Dq}-35 / 4 \mathrm{Dt} \\
\square_{2}={ }^{3} \mathrm{~B}_{2 \mathrm{~g}} \leftarrow{ }^{3} \mathrm{~B}_{1 \mathrm{~g}} & 10 \mathrm{Dq} \\
\square_{3}={ }^{3} \mathrm{~A}_{2 \mathrm{~g}} \leftarrow{ }^{3} \mathrm{~B}_{1 \mathrm{~g}} & 10 \mathrm{Dq}-4 \mathrm{Ds}-5 \mathrm{Dt} \\
\square_{4}={ }^{3} \mathrm{E}_{\mathrm{g}}^{\mathrm{b}} \leftarrow{ }^{3} \mathrm{~B}_{1 \mathrm{~g}} & 10 \mathrm{Dq}-2 \mathrm{Ds}-25 / 4 \mathrm{Dt}
\end{array}
$$

\begin{tabular}{|c|c|c|c|c|c|c|c|c|}
\hline Complexes & & $\square_{1}$ & & $\square_{2}$ & & $\square_{\mathbf{3}}$ & & $\square_{4}$ \\
\hline (1) $\mathrm{Ni}(\mathrm{TAHN})_{2} \mathrm{Br}_{2}$ & 8900 & & 10700 & & 18250 & & 24000 & \\
\hline (2) $\mathrm{Ni}(\mathrm{TAHN})_{2} \mathrm{Cl}_{2}$ & 9200 & & 10790 & & 18300 & & 24100 & \\
\hline (3) $\mathrm{Ni}(\mathrm{TAHN})_{2}(\mathrm{NCS})_{2}$ & & 9700 & & 10880 & & 18400 & & 24900 \\
\hline (4) $\mathrm{Ni}(\mathrm{TAHN})_{2}\left(\mathrm{ClO}_{4}\right)_{2}$ & & 16050 & & 20100 & & 25000 & & - \\
\hline (5) $\mathrm{Ni}(\mathrm{FPTS})_{2} \mathrm{Br}_{2}$ & & 9010 & & 10800 & & 18300 & & 24200 \\
\hline (6) $\mathrm{Ni}(\mathrm{FPTS})_{2} \mathrm{Cl}_{2}$ & & 9300 & & 10850 & & 18600 & & 24000 \\
\hline (7) $\mathrm{Ni}(\mathrm{FPTS})_{2}(\mathrm{NCS})_{2}$ & & 9810 & & 10920 & & 18400 & & 24800 \\
\hline (8) $\mathrm{Ni}(\mathrm{FPTS})_{2}\left(\mathrm{ClO}_{4}\right)_{2}$ & & 16200 & & 20300 & & 24900 & & - \\
\hline
\end{tabular}

The values of electronic bands have been displayed in table (2).

Table - 2

Values of electronic spectral bands (in $\left.\mathrm{cm}^{-1}\right)$.

$\square_{1}$ is the measure of the tetragonal character in complexes, $\square_{2}$ i.e. ${ }^{3} \mathrm{~B}_{2 \mathrm{~g}} \leftarrow{ }^{3} \mathrm{~B}_{1 \mathrm{~g}}$ however, is free from the influence of 'Ds' and 'Dt' and virtually it is the measure of the plane ligand field splitting parameter $D q_{(x, y)}$. The axial distorition ' $D t$ ' is calculated by Wentworth and Piper formula ${ }^{42}$ i.e. $D t=\frac{4}{7} D q_{(x y)}-$ $D q_{(z)}$ or by $35 / 4 \mathrm{Dt}=\square_{2}-\square_{1}$. $\mathrm{Dq}_{(\mathrm{z})}$ is derived from the expression $\mathrm{Dq}_{(\mathrm{z})}=\left(2 \square \square_{1}-\square_{2}\right) / 10$. The zero field splitting parameter has been calculated using the expression. ${ }^{43}$

\begin{tabular}{|c|c|c|c|c|c|}
\hline$\overline{\text { Complexes }}$ & $\mathrm{Dq}_{(\mathrm{xy})}\left(\mathrm{cm}^{-1}\right)$ & $\operatorname{Dq}_{(\mathrm{z})}\left(\mathrm{cm}^{-1}\right)$ & $\operatorname{Dt}\left(\mathrm{cm}^{-1}\right)$ & $K_{1}\left(\mathrm{~cm}^{-1}\right)$ & $\mathrm{D}\left(\mathrm{cm}^{-1}\right)$ \\
\hline$\left[\mathrm{Ni}(\mathrm{TAHN})_{2} \mathrm{Br}_{2}\right]$ & 1070 & 710 & 205.71 & 1800 & 13.16 \\
\hline$\left[\mathrm{Ni}(\mathrm{TAHN})_{2} \mathrm{Cl}_{2}\right]$ & 1079 & 761 & 181.71 & 1590 & 10.82 \\
\hline$\left[\mathrm{Ni}(\mathrm{TAHN})_{2}(\mathrm{NCS})_{2}\right]$ & 1088 & 852 & 134.85 & 1180 & 8.03 \\
\hline$\left[\mathrm{Ni}(\mathrm{FPTS})_{2} \mathrm{Br}_{2}\right] 1080$ & 722 & 204.57 & 1790 & 12.18 & \\
\hline$\left[\mathrm{Ni}(\mathrm{FPTS})_{2} \mathrm{Cl}_{2}\right] 1085$ & 775 & 177.14 & 1550 & 11.68 & \\
\hline$\left[\mathrm{Ni}(\mathrm{FPTS})_{2}(\mathrm{NCS})_{2}\right]$ & 1092 & 870 & 126.85 & 1110 & 8.11 \\
\hline
\end{tabular}

$$
D=\frac{9 . K_{1}}{\alpha^{2}}\left\{\frac{\mu_{e f f}}{\mu_{0}}-1\right\}^{2}
$$

The value of these parameters have been given in table- 3 .

$\underline{\text { Table }-3}$

\section{CONCLUSION}

The study reveals that the axial crystal field splitting parameter $\mathrm{Dq}_{(\mathrm{z})}$ increases from $\mathrm{Br}^{-}$to $\mathrm{NCS}^{-}$in both the series of complexes i.e. $\mathrm{NCS}^{-}>\mathrm{Cl}^{-}>\mathrm{Br}^{-}$. Tetragonal distortion parameter (Dt) however increases in the reverse order in both the series of complexes i.e. $\mathrm{NCS}^{-}<\mathrm{Cl}^{-}<\mathrm{Br}^{-}$. The parameter ' $\mathrm{K}_{1}$ ' related to the splitting of first excited term i.e. ${ }^{3} \mathrm{~T}_{2 \mathrm{~g}}$ and zero field splitting parameter ' $\mathrm{D}$ ' also increase in the same order. 


\section{ACKNOWLEDGEMENT}

One of the authors, Sahdeo Kumar is obliged to "University Grant Commission" New Delhi for awarding Rajiv Gandhi National fellowship. Vide reference no. is $\quad$ F.1-17.1/2014-15/RGNF-2014-

\section{REFERENCES}

1. Figgis, B. N. "Introduction to ligand field" Willey estern Ltd. New Delhi P. 167.

2. Michaud, A., Fontain, F. G., Zaragarian, D., (2006) "Synthesis and structural characterization of bis-and tris (3,5-dimethylpyrazolyl) methane complexes of $\mathrm{Ni}\left(\mathrm{NO}_{3}\right)_{2}$ " J. Inorg. chem. Acta, 359, 2592.,

DOI : $10.1016 /$ j.ica.2005.09.046

3. Baho, N. and Zaragarian, D., (2007) "Synthesis, Structures, Spectroscopy and Chromotropism of New complexes Arising from the reaction of $\mathrm{Ni}(\mathrm{II})$ Nitrate with Diphenyl (diphyrazoyl) methane." J. Inorg. chem., 46, 299-308.

DOI : $10.1021 /$ ic061311z.

4. Ballhausen, C. J., (1955) "On some intensity problems in absorption bands of complex ions", acta. Chem. Scand., 9, 821.

DOI : 10.3891/acta.chem.scand. 09-0821.

5. Moffitt, W. and Ballhausen, C. J.,(1956) "Quantum theory”, Ann. Rev. phys. Chem., 7, 107.

DOI : 10.1146/annurev.pc.07.100156.000543.

6. Liehr, A.D. and Ballhausen, C. J.,(1957) "Intensities in Inorganic complexes", Phys. Rev., 106, 1161. DOI : https://doi.org/10.1103/phy Rev.106.1161.

7. Agrawal, N. and Singh, A. (2013) "Synthetic, Spectroscopic, magnetic and hydrolytic studies on the first hetrotrimetallic alkoxides of Nickel(II) derived from nonalkoxo-distannate and dititanate ligands". J. Indian. Chem. soc., 90, 585.

8. Armsprong, L. G., Grimsley, P. G., Lindoy, A.F., Lip, H.C., Norris, V. A., and Smith, R. J.,(1978) "Studies involving nitrogen-oxygen donar macrocyclic ligands, 4.14 and 17-membered crown macrocycles", Inorg. Chem., 17, 2350.

DOI : 10.1021/ic50187a003

9. Prasad, R. N., Chaudhary, S. and Jain, A., (2014) "Co(II), Ni(II) complexes of 12-membered dioxadiazamacrocycles derived from $\square$-diketones and 1,8-diamino-3,6-dioxaoctane." J. Indian chem. soc., 91, 771 .

10. Ballhausen, C. J. (1962) "Introduction to ligand field theory” Mc. Graw. Hill book Company inc. New York, P-134-137.

11. Cook, C.M.,(1959) "Complexing of Tantalum pentachloride by chloride ion in fused salt media." J. Am. Chem. soc. , 81, 535-538.

DOI : $10.1021 / \mathrm{ja} 01512 \mathrm{a} 007$.

12. Amatra, H.Y., (1958) "On the absorption spectra of hexamminecobalt(III) and Related complexes. II. Theoretical study on shifting and splitting of the first and the second and due to substitution of ligands." Bull. Chem. soc. (Japan), V-31, P-95-108. DOI : http://doi.org/10.1246/bsc.31.95.

13. Muresam, N.,(2002) "Complex compounds of Nickel, Palladium and Platinum involved in electron transfer processes." J. Indian. Chem. soc., 79, 412-415.

14. Kumari, P., Prakash, S., and Prakash, D., (2012), "Synthesis and characterization of some hetero binuclear Ni(II) Schiff base complexes." J. Indian. Chem.. soc., 89, 19.

15. Sheela, A., and Harikumaran Nair, M. L., (2012), "Dioxotungsten(VI) complexes of $\square$-nitroso$\square \square$-naphthol and $\square$-nitroso- $\square \square$-naphthol." J. Indian. Chem. Soc., 89, 445.

16. Ferraro, J. R., Backer, N., (1970), "I. R. investigation of several rare-earth acetates and formats." J. Inorg. Nucl. Chem., 32(5), 1495. 
DOI : 10.1016/0022-1902(70)80637-6

17. Singh, R. B. And Srivastava, S., (2013), "Role of coordination compounds as good pesticides." J. Ind. Chem. soc., 90, 711.

18. Nakamoto, K. (1970) "INFRARED SPECTRA OF INORGANIC AND CO-ORDINATION COMPOUNDS", $2^{\text {nd }}$ edition Wiley Int. sc. New York., P. 247.

19. Borras, J., Alzuet, G., Gonzalez-alvarez, M., estevan, F., Macias, B., Liu. Gonzalez, M. and Cast, A.,(2007), "Crystal structures and spectroscopic properties of copper(II)-bis(2-pyridylcarbonyl) amide chlorobenzoate complexes." Polyhedron, V-27, P-5009-5015. DOI :10.1016/j.poly 2007.07019

20. Kumar, D. and Neelam (2012), "Synthesis, spectral and antimicrobial activity of Co(II), Ni(II), $\mathrm{Ca}(\mathrm{II})$ and $\mathrm{Zn}$ (II) metal complexes of 1-[1-(furan-2-yl)ethylidene]-2-[3-methyl-2H-benzo[e] $[1,2,4]$ oxa-diazin-2-yl (phenyl) methylene]hydrazine.” J. Ind. Chem. soc., 89, 665.

21. (Mrs.) Lawand, A. S., More, P. G., Nalwade, A. M. and Bhalvankar, R. B. (2011), "Co(II) and $\mathrm{Zn}$ (II) complexes of Schiff bases derived from fluoroaminothiazole : Spectral, Magnetic and biological studies." J. Ind. Chem. soc., 88, 781-787.

22. Harikumaran Nair, M. L. and Mariamma, A.,(2011), "Synthesis, spectral, cyclic voltammetric and biological studies of some oxomolybdenum (V) and dioxomolybdenum (VI) complexes of a Schiff base derived from 4-aminoantipyrine." J. Ind. Chem. soc., 88, 765.

23. Yaul, A. R., Dhande, V. B., Yaul, S. R., Aswar, A. S., (2011), "Transition metal complexes containing tridentate hydrazone schiff bases : Synthesis, characterization and biological sctivity." J. Ind. Chem. soc., 88, 775.

24. Reddy, K. V. R., Sagar Babu, S. V., Reddy, K. H., (2011), "Spectrophotometric determination of of copper(II) in biological samples by using 2-Acetylfuran Thiosemicarbazone as chelating agent." Asian J. chem., 23(10), P-4425.

25. Rai, B. K. and Kumar, B.,(2011), "Synthesis and characterization of $\mathrm{Ni}(\mathrm{II}), \mathrm{Cu}(\mathrm{II})$ and $\mathrm{Co}(\mathrm{II})$ complexes with Bidentate Schiff base ligand derived from 2, 3, 4, 5-Tetrahydro indeno [1,2-d] thiazolo[3, 2-a] [1, 3] pyrimidine-11(H)-one." Asian J. chem., 20(10), 4635.

26. Singh, P. and Sharma, S.,(2014) AIP conference proceeding, 1620, 385.

27. Yang, L. J., Lei, T., Liu, W., Quen chen, W., Lin, M. S., Li, L., Li, W. and Li, Y., (2012), “A sulfate-bridged $\mathrm{Cu}$ (II) complex with 1-D helical chain structure : Synthesis, Structure and magnetic property." Inorg. Chem.. commun., V-21, P-12-15. DOI : 10.1016/jinoche.2012.03.035.

28. Gill, N. S., Nuttall, R. H., Seaife, D. E., Sharp, D. W. A., (1961), "The infrared spectra of pyridine complexes and pyridinium salts." J. Inorg. Nucl. Chem., 18, 79.

DOI : 10.1016/0022-1902(61)80372-2.

29. Joseph, A., Joseph, B. and Narayana, B., (2008). "Complexes of $\mathrm{Ag}(\mathrm{I}), \mathrm{Ti}(\mathrm{I}), \mathrm{Zn}(\mathrm{II}), \mathrm{Cd}(\mathrm{II})$, $\mathrm{Hg}(\mathrm{II}), \mathrm{Co}(\mathrm{II}), \mathrm{Ni}(\mathrm{II}), \mathrm{Ru}(\mathrm{II}), \mathrm{Pd}(\mathrm{II}), \mathrm{Ru}(\mathrm{III}), \mathrm{Rh}(\mathrm{III})$ and $\mathrm{Pt}(\mathrm{IV})$ with 4-(pyridine-2carboxylidineamino)-5-mercapto-1, 2,4-triazole.” J. Ind. Chem. soc., 85, 479.

30. Kumar, D., Sharma, T., Chadda, S., and Syama, S., (2014), "Synthesis, Spectral and antimicrobial studies of the coordination compounds of the Schiff base containing aliphatic hydrazone moiety." J. Ind. Chem. Soc., 91, 185.

31. Ranjan, R., Rani, R., Suman Singh, S., Singh, A. K. and Sharma, S.,(2010), "Tetragonal distortion parameter of some nickel(II) complexes." Asian, J. chem., 22 (10) , 7580.

32. Kumar, R., Singh, P., Kumar, U., Singh, S. S., Saha, A. K. and Sharma, S., (2014), "Spectroscopic characterization of some oxovanadium (IV,V) complexes." Asian, J. Chem, 26 (16), 5298.

33. Srivastav, S. K. and Jain, S., (2015), "Synthesis and spectroscopic investigation of hetrobimetallic complexes of chlorodiphenyltin (IV) O, O'-alkylene dithiophosphates." J. Ind. Chem. Soc., 92, 183. 
34. Nair, M. L. H. and Mariama, A. T.,(2007), "Synthesis and spectral analysis of some Ru(III) complexes of azodyes derived from 1-phenyl-2,3-dimethyl-4-amino pyrazol-5-one." Asian. J. Chem, 19(6), 4653.

35. Brooks, C. J. W and Morman, J. F., (1961), "Infrared spectra of substituted salicylaldehydes." J. chem.. Soc., 3372-3381.

DOI : 10.1039/JR9610003372, paper

36. Nair, M. L. H. and Lalitha, K. P., (2011), "Synthesis spectral, thermal and electrochemical studies of iron(III) complexes with 2,3-dimethyl-1-phenyl-4-(4-methoxy-2-phenol azo)-5-pyrazolone and 2,3-dimethyle-1-phenyl-4-(3-methoxy-2-phenol zeo)-5-pyrazolone.” J. Ind. Chem. Soc., 88, 323.

37. Brubaker, G. R. and Busch, D. H., (1966), "Axial distortion and electronic structure in the macrocyclic complexes, Diacido-S,S'-o-xylyl-2,3-pentanedione bis(mercaptoethylimine) nickel (II) ${ }^{\mathrm{n}}$." Inorg. Chem., V-5, 2114-2118.

DOI : 10.1021/ic50046a007

38. Figgis, B. N.,(1964) “Introduction to ligand field theory” Mc. Graw Hill book company, inc. New York., P- 265.

39. Maki G., (1958), "Ligand field theory of Ni(II) complexes-I-electronic energies and singlet ground state conditions of $\mathrm{Ni}(\mathrm{II})$ complexes of different symmetries." J. Chem Phys, 28, 651. DOI : http://doi.org/10.1063/1.1744207

40. Maki, G., (1958), "Ligand field theory of Ni(II) complexes. II. Electronic spectra and structure of some paramagnetic chelates." J. chem. Phys, 29, 162.

DOI : http://doi.org/10.1063/1.174417

41. Abragam, A. and Pryce, M.H.L., (1951), "The theory of the nuclear Hyperfine structure of paramagnetic resonance spectra in the copper tutton salts." Proc. Roy. Soc. (London), A 206, 164, 173.

DOI : 10.1098/rspa.1951.0062.

42. Wentworth, R. A. D. and Piper, T. S. (1965), "A crystal field model for the spectral relationships in monoacidopentaamine and diacdotetraamine complexes of cobalt(III)." Inorg. Chem, V-4, P709-714.

DOI : 10.1021/ic50027a024.

43. Ranjan, R., Suraiya, A., Kumar, V. and Sharma, S., (2006) Proc. DAE-BRNS International Symposium on Material Chemistry, B.A.R.C, Mumbai, P-494, Dec. 4-8. 